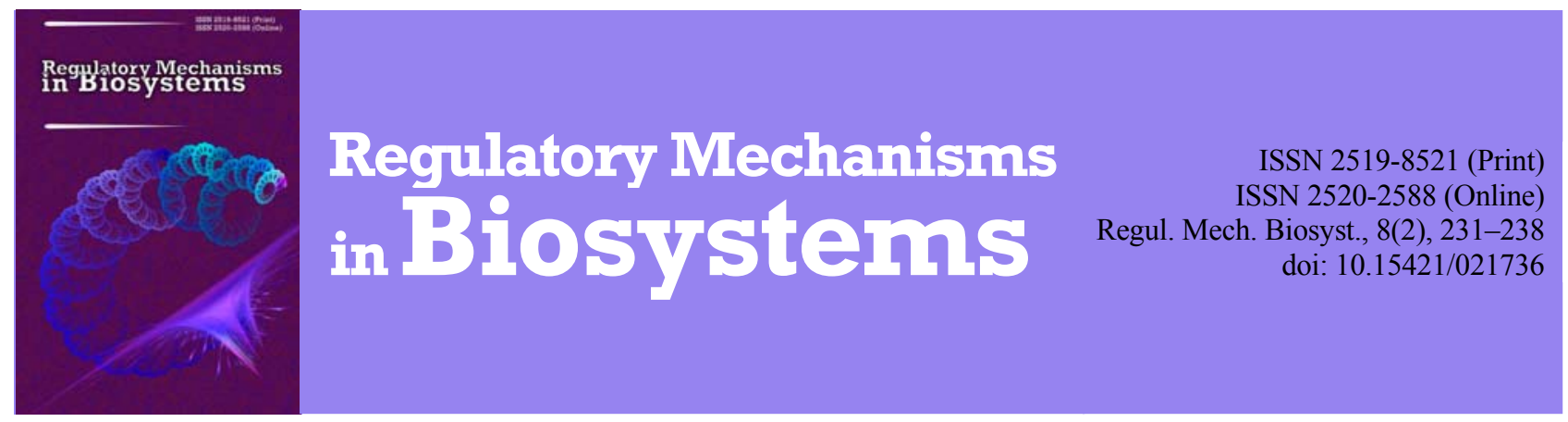

\title{
The interaction between lipid exchange and thyroid status in the conditions of prolonged influence of small doses of radiation
}

\author{
V. L. Sokolenko, S. V. Sokolenko \\ Bohdan Khmelnytsky Cherkasy National University, Chercasy, Ukraine
}

Article info

Received 29.04.2017

Received in revised form 14.05.2017

Accepted 15.05.2017

Bohdan Khmelnytsky

Cherkasy National University,

Shevchenko Str., 81 ,

Chercasy, 18031, Ukraine.

Tel.: +38-067-869-17-91.

E-mail:sokolenko@ukr.net
Sokolenko, V. L., \& Sokolenko, S. V. (2017). The interaction between lipid exchange and thyroid status in the conditions of prolonged influence of small doses of radiation. Regulatory Mechanisms in Biosystems, 8(2), 231-238. doi:10.15421/021736

We studied the interaction between the indicators of lipid exchange and thyroid status among the inhabitants of radiation contaminated territories under additional psycho-emotional load. We observed 170 students aged between 18-24 and divided them into a control group of students who were from areas unaffected by radiation (70 people) and the main experimental group of students from territories of increased radio-ecological load (IV radiation zone, 100 people). We determined the content of thyrotropic hormone (TTH), triiodothyronine $\left(\mathrm{T}_{3}\right)$, thyroxin $\left(\mathrm{T}_{4}\right)$, total cholesterin $(\mathrm{TC})$, triglycerides (TG), cholesterin of lipoproteins of high density (Ch-LPHD) and cholesterin of lipoproteins of low density (Ch-LPLD). We found that people who had lived since birth in territories which were contaminated with radionuclides and were affected by prolonged influence of small doses of ionizing radiation had significant fluctuations of indicators of concentrations of TTH, $\mathrm{T}_{3}$ and $\mathrm{T}_{4}$, forming manifestations of hypothyroidism and hyperthyrosis among some of those tested. Independently from hyperthyrosis, the effect was accompanied by growth in the level of TH, TG, ChLPHD and Ch-LPLD. Persons with manifestations of hypothyroidism had the content of TH above the upper limit of the homeostatic norm and the level of Ch-LPLD was higher than the norm in sub-groups with features of hypo- and hyperthyrosis. All those tested from the main group showed a significant positive correlation connection between the level of TTH and levels of TH and Ch-LPLD. The subgroup with manifestations of hyperthyrosis had a positive correlation between the levels of TTH and TG, the subgroups with manifestations of euthyroidism and hyperthyrosis had a negative correlation between the levels of TTH and Ch-LPHD. The hyperthyrosis subgroup had a significant positive correlation connection between $\mathrm{T}_{3}$ and $\mathrm{TH}$ and Ch-LPLD. The euthyroidism and hypothyroidism subgroups had a significant negative correlation between $\mathrm{T}_{3}$ concentration and Ch-LPLD. The cortisol indicator positively correlated with levels of TH and Ch-LPLD in all subgroups divided according to thyroid status. In the conditions of additional psycho-emotional load (examinations), those tested had an increased level of TP (higher than the norm in the subgroups of hyperthyrosis and hypothyroidism) caused by the increase in cortisol level and a tendency of decrease in TTH. At the same time, the level of Ch-LPLD increased (higher than the upper norm) as a result of decrease in the content of Ch-LPHL. The coefficient of correlation between the level of TTH and levels of TH and Ch-LPLD lost statistical significance in all subgroups divided according to thyroid status. In the hyperthyrosis subgroup, the effect of loss of correlation with TH and Ch-LPLD was also observed for $\mathrm{T}_{3}$. Thus, the individuals tested from territories polluted by radionuclides, had proaterogenic changes dependant on thyroid status, which can become a precondition for the development of metabolic syndrome. The risk of dyslipidemia increases in the conditions of additional psychoemotional load, when the regulatory effect of the thyroid gland's hormones is reduced.

Keywords: ChNPP; IV zone; fractions of cholesterol; hormones of thyroid gland; emotional stress

\section{Взаємозв'язок ліпідного обміну та тиреоїдного статусу за пролонгованого впливу малих доз радіації}

\author{
В. Л. Соколенко, С. В. Соколенко
}

\author{
Черкаський національний університет імені Богдана Хмельницького, Черкаси, Україна
}

Охарактеризовано взаємозв'язок між окремими показниками ліпідного обміну та тиреоїдного статусу осіб віком 18-24 роки, які тривалий час проживали на територіях, забруднених радіонуклідами внаслідок аварії на ЧАЕС, і зазнали пролонгованого впливу малих доз іонізуючого випромінювання. Обстежених поділено на три групи: еутиреозу, гіпертиреозу, гіпотиреозу. Виявлено варіювання рівня загального холестерину та холестерину ліпопротеїнів низької щільності залежно від тиреоїдного статусу, з можливим виходом за межі гомеостатичної норми. В усіх обстежених із дослідної групи наявний підвищений вміст загального холестерину (3Х), тригліцеридів (ТГ), холестерину ліпопротеїнів високої щільності (Хс-ЛПВЩ) та холестерину ліпопротеїнів низької щільності (Хс-ЛПНЩ). За стресу на фоні 
зростання рівня кортизолу рівень ЗХ демонстрував тенденцію до підвищення, рівень Хс-ЛПНШ достовірно зростав, Хс-ЛПВЩ знижувався. Виявлено достовірні кореляційні зв’язки між аналізованими показниками, зокрема, позитивні між ТТГ і ЗХ, ТТГ і Хс-ЛПНЩ, які нівелювалися за додаткового емоційного стресу. 3'ясовано наявність в осіб із радіаційно забруднених територій проатерогенних змін ліпідного профілю, залежних від тиреоїдного статусу, найбільше виражених за додаткового психоемоційного навантаження, коли знижується регуляторний ефект гормонів щитоподібної залози.

Ключові слова: ЧАЕС; IV зона; фракції холестерину; гормони щитоподібної залози; емоційний стрес

\section{Вступ}

Населення територій, забруднених радіонуклідами внаслідок аварії на ЧАЕС, продовжує зазнавати пролонгованого впливу малих доз іонізуючого випромінювання. Вважають, що щоденне споживання продуктів харчування, вирощених у зоні посиленого радіоекологічного контролю, залишається основним джерелом внутрішнього радіаційного опромінення, у першу чергу цезієм-137 $\left({ }^{137} \mathrm{Cs}\right)$. Хоча наслідки тривалого внутрішнього накопичення радіонуклідів досліджені поверхово, є дані про порушення у такому випадку обміну ліпідів, зокрема, метаболізму холестерину (Racine et al., 2009). Порушення ліпідного профілю та нейроендокринні форми ожиріння, зумовлені особливостями ендокринної регуляції під час пубертатного періоду, вважають вагомими причинами зростання частоти захворювань різної етіології в мешканців радіаційно забруднених територій (Korenev et al., 2009).

Одна з найуразливіших через чорнобильську катастрофу тиреоїдна система, що пояснюється іії істотним опроміненням ${ }^{131}$ I (Popovych et al., 2003). Незважаючи на тривалий час, що минув із тих пір, ризик розвитку патологій щитоподібної залози визнається досить високим як науковцями, так і медичними працівниками. Досвід Фукусіми підтвердив: навіть за малих доз опромінення зростає рівень тривожності населення щодо раку щитоподібної залози. Це вимагає постійного скринінгу груп ризику (Cardis and Hatch, 2011; Takamura et al., 2016; John et al., 2017; Rumiantsev et al., 2017).

Найвища частка раку щитоподібної залози спостерігається серед ліквідаторів, які працювали в аварійній зоні у квітні травні 1986 року (Rahu et al., 2013). Серед цивільного населення збільшення захворюваності на рак щитоподібної залози зареєстроване у дітей, які проживали у безпосередній близькості від зони інциденту. Особливу групу ризику склали особи, яким на час аварії було менше 5 років, що свідчить про високу уразливість даної вікової групи до радіаційного опромінення. Останні дані вказують на можливість віддалених тиреоїдних патологій, як наслідок тривалого низькодозового опромінення за відсутності прямого впливу радіоактивного йоду (Abou-ElArdat et al., 2012; Fushiki, 2013; Takamura et al., 2016). Часто вони поєднуються зі станом підвищеної тривожності - типової ознаки наявності стресової ситуації (Contis and Foley, 2015).

Для багатьох населених пунктів України, забруднених радіонуклідами внаслідок аварії на ЧАЕС, не проведено оцінки величини накопиченого ${ }^{131} \mathrm{I}$. Пряма сучасна дозиметрія такого накопичення неможлива через короткий період розпаду радіонукліда. Проте математичні моделі, розроблені на основі вимірювань 1986 року, дають можливість теоретично розрахувати показник на основі нинішніх даних про забруднення території ${ }^{129}$ I та ${ }^{137} \mathrm{Cs}$. Виявлено досить значну кореляцію між накопиченням радіоактивного йоду та цезію - головного фактора забруднення територій із тривалим періодом розпаду (Michel et al., 2015).

Тиреоїдні гормони, регулюючи експресію метаболічних генів, чинять вагомий вплив на ліпідний обмін, особливо на катаболізм ліпідів (Mustafina et al., 2010; Sinha et al., 2014). Boни знижують рівень холестерину у плазмі крові та підвищують експресію рецепторів до ліпопротеїнів низької щільності (ЛПНЩ-Р) у печінці, цей ефект опосередковується рецептором до тиреоїдних гормонів (TR $\beta)$. Селективні модулятори TR $\beta$-рецепторів також беруть участь у зворотному транспорті холестерину та можуть знизити рівень холестерину в сироватці крові, незалежно від рецепторів до ліпопротеїнів низької щільності, за рахунок збільшення синтезу жовчних кислот у печінці (Kan- nisto et al., 2014; Lindemann et al., 2014). Вагому роль у зв'язку ліпідного обміну та тиреоїдного статусу відіграють певні хімічні елементи, зокрема, магній і залізо (Moncayo and Monсауо, 2017). Клінічні стани, пов'язані з дисрегуляцією метаболізму ліпідів у печінці, зокрема, неалкогольні жирові хвороби печінки та цукровий діабет II типу, можуть зумовлюватися змінами внутрішньоклітинної дії тиреоїдних гормонів, особливо за вираженого гіпотиреозу (Sinha et al., 2014; van den Berg et al., 2016). Ліпідний статус жінок із гіперплазією щитоподібної залози найбільшою мірою детермінується саме тиреоїдним статусом (Beyhan et al., 2006).

Для лікування дисліпідемій використовують селективні агоністи рецепторів гормона щитоподібної залози (Taub et al., 2013). Перинатальний гіпотиреоз впливає на нейростероїдогенез у головному мозку (Chang et al., 2012). Відомі випадки впливу ліпідного обміну на тиреоїдний статус (van TienhovenWind, 2015). Підвищений рівень тригліцеридів у сироватці крові - фактор ризику раку щитоподібної залози (Radišauskas et al., 2016). Поширеність аутоімунних захворювань щитоподібної залози та гіпотиреозу досить висока серед осіб з ожирінням (Agbaht et al., 2014).

Дисфункції щитоподібної залози навіть в еутиреоїдному діапазоні зумовлюють низку проблем зі здоров'ям, включаючи розвиток атеросклерозу; це біохімічний маркер підвищеного ризику серцево-судинних порушень (van den Berg et al., 2016). Проатерогенні зміни ліпідного спектра відмічені вже за субклінічного гіпотиреозу, який виявляється нині у 5-15\% загальної людської популяції та асоціюється з підвищенням смертності від кардіоваскулярних захворювань (Beyhan et al., 2006; Barter et al., 2007; Mustafina et al., 2010; Benetti-Pinto et al., 2013). Серед факторів, що беруть участь у регуляції ліпідного обміну за субклінічного гіпотиреозу (зокрема, за рахунок зміни продукції ТТГ), вказують вік, стать, расу, спосіб життя (Duntas and Brenta, 2012).

Субклінічний гіпотиреоз асоціюється 3 підвищеним ризиком розвитку ішемічної хвороби серця та інфаркту міокарда, особливо у пацієнтів із підвщеним рівнем ТТГ (Badawy and Ghonium, 2013). Поєднання дисліпідемій із тиреоїдними дисфункціями можуть стати причинами серцево-судинних ускладнень у пацієнтів, які перебувають на гемодіалізі (Shoji et al., 2015). Важлива проблема - неможливість установлення критичних значень тиреоїдних дисфункцій, за яких виникають дисліпідемії та супутні серцево-судинні патології (Terán and Calle, 2012). Для серцево-судинної системи небезпечні як субклінічний гіпотиреоз, пов'язаний із підвищеним ризиком розвитку атеросклерозу та інфаркту міокарда, так і субклінічний тиреотоксикоз, що корелює із «серцевою» смертністю (Garasto et al., 2017).

Збільшення індексу вісцерального ожиріння супроводжується не лише несприятливими кількісними змінами ліпідного спектра сироватки крові, а й концентрації кортикостероїдів (Kushnarova et al., 2016). Ефект посилюється за тривалого хронічного стресу, що викликає дисліпідемію, гіпотиреоїдизм, зниження загального обміну, накопичення абдомінального жиру, посилення катаболізму білків (Davis et al., 2008). Кортизолемія визнаний антитиреоїдний i атерогенний фактор (Bul'ba et al., 2006). У свою чергу, метаболічні порушення, зокрема, гіперхолестеринемію, вважають можливими причинами формування депресивних станів, особливо у жінок (Rhee et al., 2014). Ожиріння та зміни ліпідного профілю на тлі гіпотиреозу поширені серед осіб із біполярними розладами (Ezzaher et al., 2011).

Хронічне нервово-психічне навантаження та вплив несприятливих екологічних, виробничих, соціальних факторів, 
які викликають гормонально-метаболічні зміни, спрямовані на підвищення енергоутворення з метою забезпечення пристосувальних процесів, можуть зумовити формування метаболічного синдрому (Beckham et al., 2003). Типовий приклад - гіперхолестеринемія та гіперкортизолемія на фоні зниженої концентрації трийодтироніну у воїнів-інтернаціоналістів та ліквідаторів наслідків аварії на ЧАЕС віком від 40 років (Balaeva-Tikhomirova, 2014). Серед синів ліквідаторів наслідків аварії на ЧАЕС характерні зміни рівня ліпопротеїнів найбільше виражені в осіб із нейроендокринним ожирінням, поширеність якого серед цієї когорти у декілька разів перевищує показники в популяції (Korenev et al., 2009). Як наслідок, в осіб, які тривалий час проживали на територіях, забруднених радіонуклідами, спостерігається зростання частоти атеросклерозу та інших серцево-судинних порушень (Bruno et al., 2013).

Взаємодія ліпідного та тиреоїдних показників за емоційного стресу досить детально вивчена на лабораторних тваринах (Zhigulina, 2015). Дослідження зв'язку між ліпідним обміном і тиреоїдним статусом мешканців радіаційно забруднених районів стосуються в основному дітей або осіб похилого віку, чи пацієнтів із вираженими патологіями, тому вимагають подальшого аналізу.

Мета статті - з'ясувати особливості взаємозв'язку між основними показниками ліпідного обміну та тиреоїдного статусу в мешканців радіаційно забруднених територій за відсутності та наявності додаткового психоемоційного навантаження.

\section{Матеріал і методи досліджень}

Обстежено 170 осіб, серед яких виділили групу мешканців радіаційно незабруднених районів (контрольна група, 70 осіб) i мешканців територій посиленого радіоекологічного контролю (IV радіаційна зона, щільність забруднення грунтів ізотопами ${ }^{137} \mathrm{Cs} 3,7 \cdot 10^{4}-18,5 \cdot 10^{4}$ Бк/ $\mathrm{M}^{2}, 100$ осіб). Усі обстежені - студенти Черкаського національного університету віком 18-24 роки, які на час обстеження не мали гострих захворювань. Між показниками волонтерів різних статей (осіб жіночої статі обстежували у фолікулярну стадію менструального циклу) не спостерігали статистично вірогідної різниці, тому надалі їх розглядали як єдину сукупність.

Роль додаткового стресового фактора, що зумовив розвиток психоемоційного навантаження, відіграла зимова екзаменаційна сесія. В обстежених вранці (до вживання їжі) відбирали 15 мл венозної крові. Перший аналіз показників проводили в міжсесійний період, другий - після першого іспиту.

Вміст кортизолу у сироватці крові визначали імуноферментним методом із використанням набору «BIO-RAD» (Poсія). Вміст тиреотропного гормона (ТТГ) визначали за допомогою тест-набору PIA-TTГ (Immunotech, Чехія). Вміст тироксину $\left(\mathrm{T}_{4}\right)$ у сироватці крові досліджували за допомогою тестнабору pio-т4-іПр, трийодтироніну $\left(\mathrm{T}_{3}\right)$ - pio-т3-іПр (Інститут біоорганічної хімії Національної академії наук Республіки Білорусь). Рівень загального холестерину (ЗХ), тригліцеридів (ТГ), холестерину ліпопротеїнів високої щільності (Хс-ЛПВЩ) визначали методом Лібермана - Бурхарда. Вміст холестерину ліпопротеїнів низької щільності (Хс-ЛПНЩ) визначали за формулою Фрідвальда: Хс-ЛПНЩ = 3X - (Хc-ЛПВЩ + ТГ/2,2) $(\mathrm{Zak}, 1980)$.

У межах дослідної групи виділили підгрупу еутиреозу (31 особа), підгрупи з ознаками гіпертиреозу (48 осіб) та гіпотиреозу (21 особа). Діагноз про наявність синдрому ВСД ставили лікарі студентського санаторію-профілакторію «Едем» при університеті.

Статистичну обробку результатів проводили методами варіаційної статистики. Дані наведені у вигляді: середнє арифметичне \pm похибка середнього арифметичного $(\mathrm{M} \pm \mathrm{m})$. Достовірність різниці між показниками визначали за t-критерієм Стьюдента, попередньо перевіривши вибірки на нормальність розподілу. Кореляційний аналіз проводили 3 використанням коефіцієнта кореляції Пірсона.

\section{Результати}

В обстежених контрольної групи більшість показників перебувала в межах гомеостатичної норми (Zak, 1980), показники ліпідного профілю зміщені до нижньої межі норми, що могло зумовлюватися особливостями харчування студентів (табл.).

В осіб, які зазнали пролонгованого впливу малих доз іонізуючого випромінювання, спостерігали значне варіювання показників концентрації ТТГ, $\mathrm{T}_{3}$ та $\mathrm{T}_{4}$ у периферичній крові. Проте серед них досить чітко виділили підгрупу еутиреозу, а також підгрупи з ознаками гіпертиреозу та гіпотиреозу. Поділ робили за вмістом трийодтироніну, чия біологічна ефективність вища, ніж у $\mathrm{T}_{4}$ (Klein, 2004).

За відсутності додаткового психоемоційного навантаження в обстежених із підгрупи еутиреозу рівень $\mathrm{T}_{3} \mathrm{i}_{4}$ статистично не відрізнявся від контрольних значень. В осіб з ознаками гіпертиреозу показники достовірно вищі контролю, з ознаками гіпотиреозу - нижчий вміст $\mathrm{T}_{3}$. Концентрація ТТГ в обстежених 3 ознаками гіпотиреозу та гіпертиреозу вища контролю (табл.).

За результатами медичного анамнезу серед обстежених відсутні особи з клінічними проявами патології щитоподібної залози. Проте у 17 осіб з ознаками гіпотиреозу ( $81 \%$ від обстежених у підгрупі), 26 осіб з ознаками гіпертиреозу (54\% від обстежених у підгрупі) та 7 із підгрупи еутиреозу (23\% від обстежених у підгрупі) спостерігалися ознаки синдрому вегето-судинної дистонії.

В усіх обстежених із територій посиленого радіоекологічного контролю, незалежно від тиреоїдного статусу, рівень загального холестерину, тригліцеридів, холестерину ліпопротеїнів високої та низької щільності вищий, ніж у контролі. В осіб з ознаками гіпотиреозу тенденція до зростання рівнів загального холестерину та холестерину ліпопротеїнів низької щільності виражена найбільше, і показники достовірно вищі, порівняно 3 отриманими для підгрупи еутиреозу (табл.). У цій підгрупі вміст холестерину перевищив верхню межу гомеостатичної норми, вказаної в літературі (Zak, 1980). Рівень Хс-ЛПНЩ вийшов за верхню межу норми у підгрупах з ознаками гіпо- та гіпертиреозу.

Кореляційний аналіз показав, що у мешканців територій, забруднених радіонуклідами, незалежно від тиреоїдного статусу, спостерігається достовірний позитивний зв'язок між рівнем ТТГ і рівнями 3Х та Хс-ЛПНЩ. Також виявлено позитивну кореляцію між рівнями ТТГ і тригліцеридів у підгрупі з ознаками гіпертиреозу; негативну кореляцію - між рівнями ТТГ і Хс-ЛПВЩ у підгрупах з ознаками еутиреозу та гіпертиреозу (рис. 1-3).

Рівні $\mathrm{T}_{4}$ i $\mathrm{T}_{3}$ демонстрували негативну кореляцію з рівнем загального холестерину, тригліцеридів, Хс-ЛПВЩ у підгрупах еутиреозу та гіпотиреозу, проте вона не мала статистичної значущості. У підгрупі гіпертиреозу для трийодтироніну виявлено достовірний позитивний кореляційний зв'язок із рівнем загального холестерину та Хс-ЛПНЩ. У підгрупах еутиреозу та гіпотиреозу - достовірна негативна кореляція концентрації $\mathrm{T}_{3}$ із рівнем Хс-ЛПНЩ (рис. 1-3).

В осіб із дослідної групи навіть за відсутності додаткових стресових чинників спостерігали достовірне підвищення рівня кортизолу порівняно 3 контролем. Показник позитивно корелював із рівнями $3 \mathrm{X}$ та Хс-ЛПНЩ у всіх підгрупах (рис. 1-3), негативно - із рівнем Хс-ЛПВЩ у підгрупі гіпертиреозу (рис. 2). Під час екзаменаційної сесії як фактора психоемоційного навантаження для студентів рівень кортизолу достовірно зростав порівняно $з$ міжсесійним періодом і в контрольній, і в дослідних групі (табл.).

У студентів, які приїхали на навчання з територій, забруднених радіонуклідами, стрес-індукований ефект зростання концентрації кортизолу проявлявся незалежно від тиреоїдного статусу. Паралельно спостерігали тенденцію до зниження вмісту ТТГ, в осіб з ознаками гіпертиреозу достовірно знизився вміст $\mathrm{T}_{3}, \mathrm{~T}_{4}$ залишився без змін. В осіб із підгрупи еутиреозу $\mathrm{T}_{3}$ демонстрував тенденцію до зниження, 3 підгрупи гіпотиреозу - 
істотні коливання показника відсутні (табл.). Рівень загального холестерину демонстрував тенденцію до зростання в усіх трьох підгрупах (у підгрупах гіпертиреозу та гіпотиреозу вийшов за верхню межу норми, за еутиреозу досяг цієї межі), при цьому достовірно підвищувався рівень холестерину ліпоротеїнів низь- кої щільності (з виходом за верхню межу норми) на фоні зниження вмісту холестерину ліпопротеїнів високої щільності. Тригліцериди демонстрували лише тенденцію до зростання, у підгрупі гіпотиреозу показник став вищим порівняно $з$ підгрупою еутиреозу (табл.).

\section{Таблиця}

Показники вмісту кортизолу, ліпідного обміну та тиреоїдного статусу в обстежених

(до емоційного стресу - верхній рядок, під час емоційного стресу - нижній рядок, $\mathrm{M} \pm \mathrm{m}$ )

\begin{tabular}{|c|c|c|c|c|}
\hline \multirow{2}{*}{ Показники } & \multirow{2}{*}{ Контроль, $\mathrm{n}=70$} & \multicolumn{3}{|c|}{ Дослідна група: особи, які зазнали пролонгованого впливу малих доз радіації, $\mathrm{n}=100$} \\
\hline & & еутиреоз, $\mathrm{n}=31$ & гіпертиреоз, $\mathrm{n}=48$ & гіпотиреоз, $\mathrm{n}=21$ \\
\hline \multirow{2}{*}{ Кортизол, нмоль/л } & $349,0 \pm 9,86$ & $629,5 \pm 18,01 *$ & $633,8 \pm 19,01^{*}$ & $624,9 \pm 17,36^{*}$ \\
\hline & $691,2 \pm 12,13 * *$ & $881,1 \pm 15,21 * * *$ & $890,1 \pm 18,65 * * *$ & $877,4 \pm 20,01 * * *$ \\
\hline \multirow{2}{*}{ Загальний холестерин (3Х), ммоль/л } & $3,05 \pm 0,265$ & $4,75 \pm 0,489^{*}$ & $5,84 \pm 0,710^{*}$ & $7,13 \pm 0,810^{*} \#$ \\
\hline & $3,29 \pm 0,315$ & $5,99 \pm 0,725^{*}$ & $7,05 \pm 0,584^{*}$ & $7,48 \pm 0,518^{*}$ \\
\hline \multirow{2}{*}{ Тригліщериди (ТГ), ммоль/л } & $0,52 \pm 0,063$ & $0,81 \pm 0,071^{*}$ & $0,91 \pm 0,072 *$ & $1,01 \pm 0,081 *$ \\
\hline & $0,55 \pm 0,072$ & $0,96 \pm 0,059^{*}$ & $1,09 \pm 0,061^{*}$ & $1,16 \pm 0,074^{*}, \#$ \\
\hline \multirow{2}{*}{$\begin{array}{l}\text { Холестерин ліпопротеїнів високої } \\
\text { щільності (Хс-ЛПВЩ), ммоль/л }\end{array}$} & $1,05 \pm 0,065$ & $1,63 \pm 0,081^{*}$ & $1,50 \pm 0,071 *$ & $1,44 \pm 0,079^{*}$ \\
\hline & $0,97 \pm 0,085$ & $1,13 \pm 0,071 * *$ & $0,95 \pm 0,069 * *$ & $0,91 \pm 0,075^{* *} \#$ \\
\hline \multirow{2}{*}{$\begin{array}{l}\text { Холестерин ліпопротеїнів низької } \\
\text { щільності (Хс-ЛПНЩ), ммоль/л }\end{array}$} & $1,81 \pm 0,114$ & $2,81 \pm 0,317^{*}$ & $3,94 \pm 0,499^{*}$ & $5,22 \pm 0,256^{*,} \#$ \\
\hline & $2,05 \pm 0,134$ & $4,39 \pm 0,389 * * *$ & $5,62 \pm 0,245^{*, * *, \#}$ & $6,05 \pm 0,199 * * * * \#$ \\
\hline \multirow{2}{*}{$\begin{array}{l}\text { Тиреотропний гормон (ТТГ), } \\
\text { мкОД./мл }\end{array}$} & $2,31 \pm 0,212$ & $3,05 \pm 0,416$ & $3,67 \pm 0,245^{*}$ & $3,74 \pm 0,210^{*}$ \\
\hline & $2,32 \pm 0,351$ & $2,44 \pm 0,275$ & $2,74 \pm 0,458$ & $2,81 \pm 0,490$ \\
\hline \multirow{2}{*}{ Трийодтиронін ( $\left.\mathrm{T}_{3}\right)$, нмоль/л } & $1,54 \pm 0,056$ & $1,56 \pm 0,045$ & $2,59 \pm 0,068^{*} \#$ & $0,75 \pm 0,031^{*}, \#$ \\
\hline & $1,41 \pm 0,061$ & $1,45 \pm 0,044$ & $1,71 \pm 0,069^{* * * *} \#$ & $0,73 \pm 0,045^{*} \#$ \\
\hline \multirow{2}{*}{ Тироксин $\left(\mathrm{T}_{4}\right)$, нмоль/л } & $81,6 \pm 5,73$ & $96,0 \pm 6,43$ & $127,3 \pm 6,25^{*} \#$ & $78,2 \pm 8,31 \#$ \\
\hline & $76,8 \pm 9,13$ & $94,3 \pm 7,12$ & $121,0 \pm 8,49^{*} \#$ & $77,1 \pm 5,39 \# 4$ \\
\hline
\end{tabular}

Примітки: * - P < 0,05 порівняно з контролем; ** - P < 0,05 порівняно з показником до психоемоційного навантаження; \# - $\mathrm{P}<0,05$ порівняно 3 показником у підгрупі еутиреозу.

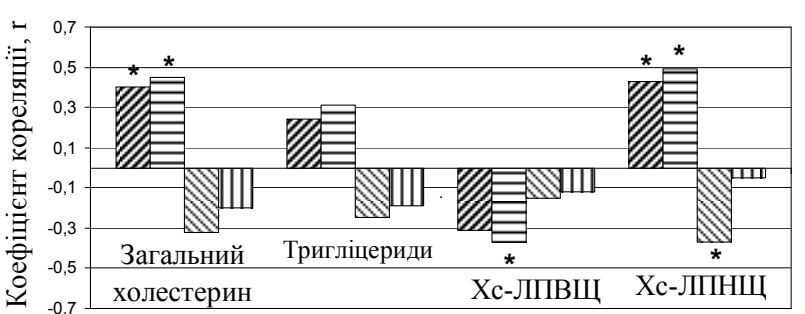

\section{ॠ із кортизолом}

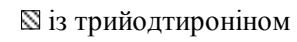

目 із тиреотропним гормоном

Ш із тироксином

Рис. 1. Кореляційна залежність між аналізованими показниками ліпідного обміну та ендокринного статусу у підгрупі еутиреозу, до емоційного стресу:

* - достовірність коефіцієнту кореляції $\mathrm{P}<0,05$

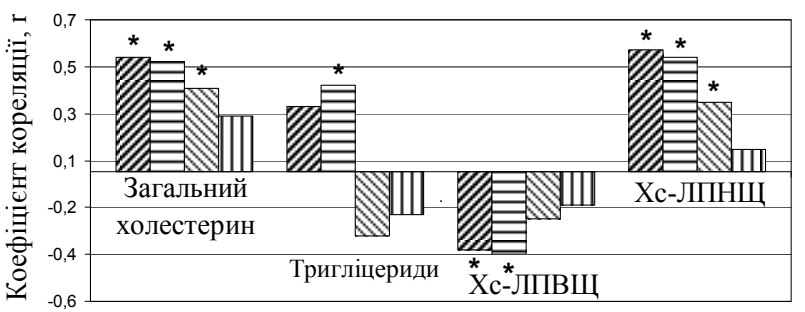

\section{叉 із кортизолом}

$\mathbb{\mathrm { Q }}$ із трийодтироніном $\boxminus$ із тиреотропним гормоном

Ш із тироксином
Рис. 2. Кореляційна залежність між аналізованими показниками ліпідного обміну та ендокринного статусу у підгрупі гіпертиреозу, до емоційного стресу: див. рис. 1

В усіх підгрупах, поділених за тиреоїдним статусом, коефіцієнт кореляції між рівнем ТТГ і рівнями загального холестерину та Хс-ЛПНЩ втратив статистичну достовірність (рис. 4-6). У підгрупі гіпертиреозу ефект втрати кореляції із загальним холестерином та Хс-ЛПНЩ відмічено також для трийодтироніну (рис. 5). Спостерігали негативну кореляцію $\mathrm{T}_{3}$ iз Хс-ЛПНЩ у підгрупах гіпертиреозу (зі зміною знака кореляції порівняно з достресовим періодом) та гіпотиреозу. В осіб
3 ознаками гіпотиреозу негативну кореляцію з кортизолом демонстрував Хс-ЛПВЩ (рис. 6); позитивна кореляція з кортизолом збереглася для 3Х і ЛПНШ у всіх трьох підгрупах, поділених за тиреоїдним статусом (рис. 4-6).

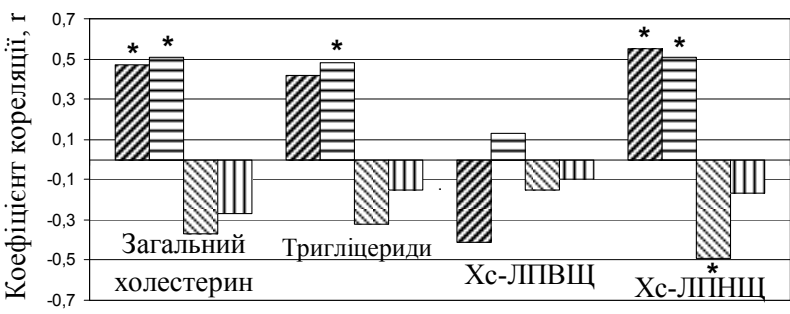

\section{із кортизолом}

$\boxminus$ із тиреотропним гормоном

\із трийодтироніном

II із тироксином

Рис. 3. Кореляційна залежність між аналізованими показниками ліпідного обміну та ендокринного статусу у підгрупі гіпотиреозу, до емоційного стресу: див. рис. 1

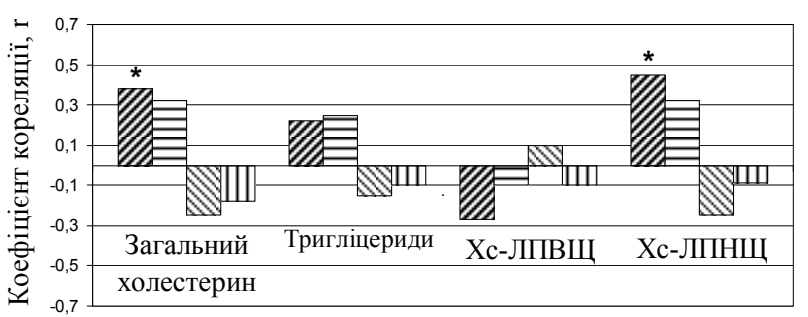

ॠ 3 кортизолом $\boxminus$ із тиреотропним гормоном \із трийодтироніном

पा із тироксином

Рис. 4. Кореляційна залежність між аналізованими показниками ліпідного обміну та ендокринного статусу у підгрупі еутиреозу під час емоційного стресу; див. рис. 1

\section{Обговорення}

У практично здорових осіб і пацієнтів, які перебувають у стані стійкої ремісії, складно аналізувати взаємопов'язані зміни показників ендокринної регуляції та метаболізму, оскільки 
коливання в межах норми рівнів гормонів і метаболітів досить значні. Можливим шляхом вирішення даної проблеми вважають дослідження гормонально-метаболічних взаємовідносин в осіб, які зазнавали тривалого впливу факторів, що вимагали мобілізації регуляторних систем (Balaeva-Tikhomirova, 2014). До таких факторів належить, зокрема, пролонговане опромінення малими дозами радіації.

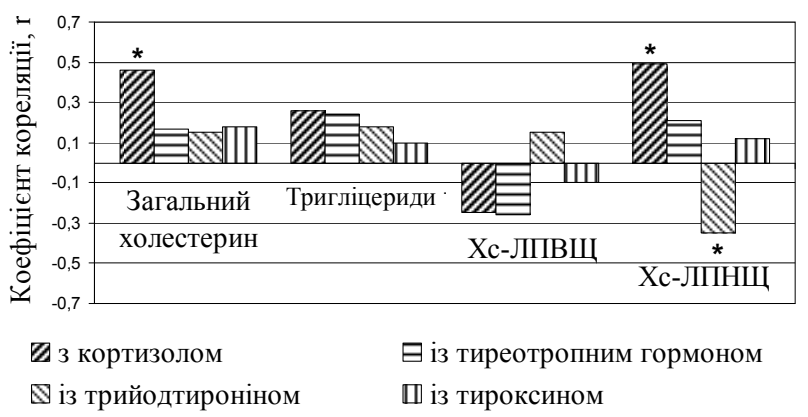

Рис. 5. Кореляційна залежність між аналізованими показниками ліпідного обміну та ендокринного статусу у підгрупі гіпертиреозу під час емоційного стресу: див. рис. 1

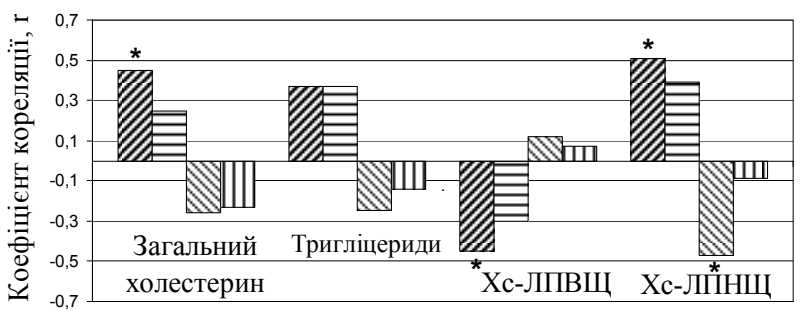
з кортизолом
\$ із трийодтироніном
$\Xi$ із тиреотропним гормоном
Ш із тироксином

Рис. 6. Кореляційна залежність між аналізованими показниками ліпідного обміну та ендокринного статусу у підгрупі гіпотиреозу під час емоційного стресу: див. рис. 1

Аналіз результатів досліджень показав, що у мешканців території посиленого радіоекологічного контролю спостерігали певне напруження тиреоїдного статусу, що характеризувалося підвищеною концентрацією ТТГ в осіб із досить високим вмістом $\mathrm{T}_{3}$ у периферичній крові. Ефект супроводжувався підвищенням рівня загального холестерину, тригліцеридів, холестерину ліпопротеїнів високої та низької щільності, причому в осіб з ознаками гіпотиреозу тенденція до зростання рівнів загального холестерину та холестерину ліпопротеїнів низької щільності проявлялася найбільше (табл.).

Отримані дані узгоджуються з повідомленнями про те, що пацієнти 3 вираженим гіпотиреозом мають значно вищий рівень загального холестерину, ніж із еутиреозом, із субклінічним - зміни менш відчутні (Shavdatuashvili, 2005). Підвищення рівня загального холестерину у сироватці крові за гіпотиреозу логічне. Тиреоїдині гормони стимулюють утилізацію жирів, мобілізацію тригліцеридів із жирової тканини, активують печінкову ліпазу та ефір-холестерин-трансформувальний білок, рівень якого підвищений за тиреотоксикозу та знижений за гіпотиреозу (Dedecjus et al., 2003; Duntas, 2003). Тиреоїдні дисфункції, зокрема, виражений або субклінічний гіпотиреоз, здатні змінити ліпідний профіль і сприяти розвитку серцевосудинних захворювань. Гіперхолестеринемія за гіпотиреозу зумовлюється зниженням експресії рецепторів до холестерину ліпопротеїнів низької щільності та зменшенням контролю 3 боку $\mathrm{T}_{3}$ над білком, що контролює обмін стеринів в організмі людини (SREBP-2), який має вирішальне значення для експресії рецепторів до ЛПНЩ. Дія гормонів щитоподібної залози на жовчні кислоти останнім часом розглядається як істотний гіпохолестеринемічний фактор. Високі титри тиреотропного гормона асоціюються з проатерогенними змінами ліпідного про- філю (Duntas and Brenta, 2012). Як наслідок, такі зміни спостерігають у переважної більшості пацієнтів із гіпотиреозом і характеризують наявністю значної позитивної кореляції між концентраціями ТТГ і загального холестерину (Iqbal et al., 2006; Mustafina et al., 2010). Вважають, що ефект зумовлюється уповільненням швидкості метаболізму ліпідів на фоні активації їх синтезу (Abrams and Grundy, 1981). Таким чином, виявлене нами зростання рівня холестерину та Хс-ЛПНЩ з ознаками гіпертиреозу можна пояснити нетиповим підвищенням в обстежених рівня ТТГ як важливого проатерогенного фактора. Дані літератури підтверджують, що підвищення рівня холестерину - зазвичай супутній фактор підвищення рівня ТТГ (Pirich et al., 2000).

В обстежених нами мешканців територій, забруднених радіонуклідами, достовірний позитивний коефіцієнт кореляції між рівнем ТТГ і рівнями загального холестерину, холестерину ЛПНЩ характерний для всіх трьох груп, поділених за тиреоїдним статусом; між рівнями ТТГ і тригліцеридів - для групи з ознаками гіпертиреозу (рис. 1-3).

Епідеміологічні дані свідчать, що рівень ТТГ тісно корелює зі ступенем тяжкості гіперхолестеринемії. Проте молекулярний механізм участі гіперхолестеринемії у розвитку субклінічного гіпотиреозу з'ясований не остаточно. Вважають, що ефект зумовлений процесами, залученими до зворотного транспорту холестерину, який, у свою чергу, відіграє важливу роль у регуляції рівня холестерину. В експериментах на тваринах показано, що ТТГ може стимулювати печінкові АТФ-зв'язувальні касетні транспортери, що забезпечують передачу внутрішньоклітинного холестерину у плазму крові (Zhang et al., 2016).

У літературі зустрічаються дані, відмінні від отриманих нами. Атерогенні порушення ліпідного профілю в індійського населення із субклінічним гіпотиреозом спостерігали лише у випадку зростання концентрації ТТГ понад 10,0 мМО/л і характеризували підвищенням рівня загального холестерину та холестерину ЛПНЩ. В осіб із ТТГ меншим за 10,0 мМО/л його рівень позитивно корелював із вмістом $\mathrm{T}_{3} \mathrm{i} \mathrm{T}_{4}$, негативно - iз рівнем загального холестерину та холестерину ЛПНЩ (Marwaha et al., 2011). Такі особливості можуть зумовлюватися віком, статтю, расою, способом життя (Duntas and Brenta, 2012).

Як указувалося вище, в обстежених із дослідної групи, незалежно від тиреоїдного статусу, спостерігали достовірне підвищення, порівняно з контролем, рівня тригліцеридів (ТГ), холестерину ліпопротеїнів високої (Хс-ЛПВЩ) та низької (ХcЛПВЩ) щільності (табл.). Зростання вмісту тригліцеридів у сироватці крові класифікують як проатерогенні зміни ліпопротеїнового профілю (Duntas and Brenta, 2012). Таке явище, поряд зі зниженням рівня антиатерогенної фракції холестерину (ЛПВЩ), асоціюється 3 порушенням енергетичного та ліпідного гомеостазу в організмі та підвищеним ризиком серцево-судинних ускладнень. Підвищення рівня ТГ може відображати уповільнення поглинання та засвоєння клітинами жирних кислот (Kushnarova et al., 2016).

Тригліцериди - основний ліпідний компонент ліпопротеїнів наднизької щільності, що містить мало холестерину; саме вони - провідний транспортер холестерину з печінки у кров. Ліпопротеїни низької щільності - транспортна форма холестерину та ненасичених жирних кислот від печінки до органів $\mathrm{i}$ тканин. ЛПНЩ малорозчинні та схильні до формування атеросклеротичних бляшок у судинах, що зумовлено підвищеною здатністю втрачати холестерин під час транспортування. Значна частина ЛПНЩ захоплюється печінкою та іншими периферичними клітинами шляхом рецептор-опосередкованого ендоцитозу. Ліпопротеїни високої щільності здійснюють зворотний транспорт холестерину у печінку. Це високомолекулярна легкорозчинна форма, яка не випадає в осад. Відповідно, ЛПВЩ відіграють протекторну роль щодо відкладення ліпідів у атеросклерозних бляшках (Prasad et al., 2012; Kaur, 2014; Kushnarova et al., 2016).

Виявлене нами підвищення рівня холестерину ліпопротеїнів високої щільності в дослідній групі можна розглядати як 
компенсаторну реакцію на збільшення проатерогенних фракцій холестерину. Протекторну функцію цієї фракції підтверджує негативна кореляція між рівнями ТТГ та Хс-ЛПВЩ у групах з ознаками еутиреозу та гіпертиреозу (рис. 1, 2).

Виразність порушень ліпідного обміну не лише прямо пропорційна рівню тиреотропного гормона, а й обернено пропорційна рівню тироксину. Низький рівень вільного $\mathrm{T}_{4}$ асоціюється 3 проявами метаболічного синдрому, ожирінням, рівень ТТГ детермінується інверсійно рівнем $\mathrm{T}_{4}$ більшою мірою, ніж рівнем $\mathrm{T}_{3}$ (Bul'ba et al., 2006; Mustafina et al., 2010).

У наших дослідженнях відсутні виражені зв'язки тироксину 3 показниками ліпідного профілю. Для трийодтироніну виявлено достовірний позитивний кореляційний зв'язок із рівнем загального холестерину та Хс-ЛПНЩ у підгрупі гіпертиреозу, що не можна вважати типовим ефектом. У підгрупах еутиреозу та гіпотиреозу достовірна кореляція концентрації $\mathrm{T}_{3}$ iз рівнем Хс-ЛПНЩ негативна (рис. 1-3). Згідно з даними літератури, $\mathrm{T}_{3}$ стимулює різні метаболічні шляхи та печінкові функції переважно через $\beta$-рецептори до гормона щитоподібної залози (TR $\beta)$. Тиреоїдні гормони пов'язані із секреторними фосфоліпазами, які, у свою чергу, беруть участь у процесах запалення, гіперліпідемії та атеросклерозу. $\mathrm{T}_{3}$, знижуючи синтез фосфоліпази, обмежує розвиток гіперліпідемії та запальних процесів (Sharma et al., 2014).

Як повідомлялося в наших попередніх дослідженнях, найвищий рівень загального холестерину у дослідній групі спостерігався для осіб з ознаками синдрому вегето-судинної дистонії (Sokolenko, 2016). Синдром відмічено у $81 \%$ обстежених із групи гіпотиреозу, $54 \%$ із групи гіпертиреозу, $23 \%$ із групи еутиреозу. Тобто дисбаланс рівня тиреоїдних гормонів у мешканців територій, забруднених радіонуклідами, стає фактором розвитку не лише змін метаболізму ліпідів, а й вегето-судинних дисфункцій.

Гіперліпідемія вважається істотним чинником ризику серцево-судинної патології, тому гіпотиреоз опосередковано сприяє іiі розвитку. Для пацієнтів з ішемічною хворобою серця досить характерне підвищення загального рівня холестерину на фоні клінічного гіпотиреозу (Beyhan et al., 2006). Можлива причина тривалий субклінічний гіпотиреоз (синдром еутиреоїдної слабкості), порушення ліпідного обміну, що спричинює прогресування атеросклерозу та підвищенню загального периферичного судинного опору, здатного погіршити перебіг артеріальної гіпертонії (Nikolaev et al., 2012). Субклінічні випадки дисфункцій щитоподібної залози, що характеризуються нормальним рівнем тироксину $\left(\mathrm{T}_{4}\right)$, але зміненим рівнем тиреотропного гормона (ТТГ), також вважають фактором ризику серцево-судинних i метаболічних захворювань. Подібний ефект може проявлятися не лише за зростання, а й під час наближення рівня ТТГ до нижньої межі норми (в межах нормального діапазону) (Laclaustra et al., 2015). Показано позитивну кореляцію між рівнями сироваткових $\mathrm{T}_{4}$ i холестерину ліпопротеїнів низької щільності, сироваткового ТТГ і холестерину ліпопротеїнів високої щільності, значні негативні кореляції між рівнями сироваткового ТТГ і тригліцеридів в еутиреоїдних осіб із серцево-судинними хворобами (Takeuchi, 2015).

У нашому випадку синдром вегето-судинної дистонії спостерігався у багатьох осіб з ознаками гіпертиреозу. Такий наслідок міг зумовлюватися тим, що у даній групі вміст загального холестерину та холестерину ліпопротеїнів низької щільності, як і за гіпотиреозу, достовірно вищий контролю (табл.). Крім того, в реалізацію ефекту міг включатися фактор радіаційного впливу, зокрема, радіаційно індуковані зміни реакцій ліпідного обміну та порушення автономної нервової регуляції (Janssen et al., 2005; Baker et al., 2011).

Пролонговане радіаційне опромінювання варто розглядати як хронічний стресовий фактор (Tronko et al., 1996). Його наслідок - часто неадекватна адаптація, яка полягає у виділенні значної кількості кортизолу на фоні зниження вмісту антистресових гормонів. При цьому виникає низка руйнівних метабо- лічних процесів, проявами яких можуть бути виявлені нами ефекти (Davis et al., 2008).

Справді, у дослідній групі відмічено достовірне підвищення рівня кортизолу порівняно $з$ контролем за відсутності дії додаткових стресових факторів (табл.). Кортизол збільшує активність ліпопротеїнліпази, сприяючи зростанню рівня Хс-ЛПНЩ. Одночасно він знижує утворення рецепторів до Хс-ЛПНЩ, гальмуючи їх поглинання клітинами та елімінацію холестерину 3 кровотоку (у тому числі у печінку), підвищує активність ліпази, що вивільняє жирні кислоти з депонованих тригліцеридів. Виявлено залежність між хронічним емоційним або психосоціальним стресом і атеросклерозом коронарних артерій; компоненти метаболічного синдрому (ожиріння, гіпертонія, дисліпідемія) проявляються за хронічного психологічного стресу, депресії, низького соціально-економічного статусу. У багатьох випадках важко говорити про первинність чи вторинність взаємодій кортикоїдних гормонів та ліпідного обміну (Brotman et al., 2007; Engelking, 2010; Toth et al., 2014).

За останні роки значно розширилися уявлення про стрес як розгалужену системну реакцію організму, яка, за певних умов, може спричинювати порушення функцій багатьох фізіологічних систем, зокрема, серцево-судинної, нервової; дисфункції ендокринної системи на рівні продукції катехоламінів, гормонів щитоподібної, статевих залоз. Ранні життєві психічні травми у підлітків супроводжуються зниженням рівня трийодтироніну (Machado et al., 2015). Гострий стрес у людей характеризується активацією ліполізу, переважаючими енергосубстратами виступають ліпіди. Хронічний емоційний стрес викликає зростання рівня холестерину на фоні активації секреції катехоламінів, у результаті чого посилюється мобілізація жирової тканини 3 утворенням вільних жирних кислот, що надходять у кров (Zhigulina, 2015). В осіб, які зазнали гострого стресу, piвень Хс-ЛПНЩ вищий, ніж за помірного стресу (O'Connor et al., 2009). За депресивних розладів, які тривали не менше трьох років, спостерігали підвищення рівня тригліцеридів i нижчі рівні Хс-ЛПВЩ, ТТГ і $\mathrm{T}_{4}$ порівняно $з$ даними для пацієнтів із депресивним синдромом, тривалістю менше трьох років. При цьому відмічено значний позитивний зв'язок ТТГ із рівнем загального холестерину та холестерину ЛПНЩ, рівні $\mathrm{T}_{4} \mathrm{i} \mathrm{T}_{3}$ негативно корелювали з рівнем загального холестерину, холестеринами ЛПВЩ і ЛПНЩ. Сироваткові рівні тригліцеридів і ТТГ залежали від тривалості депресивних симптомів (Peng and Li, 2017). Під час критичних захворювань, що загрожують життю, зростання рівня кортизолу супроводжувалося зниженням концентрації $\mathrm{T}_{3}$ i підвищенням рівня ТТГ $\mathrm{i} \mathrm{T}_{4}$ (Vermes and Beishuizen, 2007).

Дані, отримані під час екзаменаційної сесії як фактора додаткового психоемоційного навантаження, значною мірою узгоджуються 3 оприлюдненими в літературі: зростання рівня кортизолу, незалежно від тиреоїдного статусу, вихід Хс-ЛПННЩ за верхню межу норми. Рівень загального холестерину, хоч і не зазнав достовірних змін, сягав вищої межі норми за еутиреозу та перевищив норму в осіб з ознаками гіпотиреозу та гіпертиреозу (табл.). Відсутність достовірної динаміки вмісту загального холестерину в умовах психоемоційного навантаження може зумовлюватися відсутністю вірогідних змін ТТГ і тироксину. Інша можлива причина такого ефекту - достовірне зростання рівня Хс-ЛПНЩ компенсувалося зниженням Хс-ЛПВЩ.

Втрата достовірності коефіцієнтом кореляції між рівнем 3X і ТTГ, в умовах психоемоційного навантаження, та зміна знаку коефіцієнта між $\mathrm{T}_{3}$ і ЛПНЩ у групі гіпертиреозу свідчать про нівелювання значення ТТГ і тиреоїдних гормонів у реалізації ліпідного обміну. 3 одного боку, це можна пояснити значним зростанням рівня кортизолу та його пріоритетом у виявлених реакціях, що підтверджувалося стабільним позитивним коефіцієнтом кореляції між концентрацією кортизолу та рівнями загального холестерину та холестерину ліпопротеїнів низької щільності (рис. 4-6). 3 іншого, підвищений рівень $3 \mathrm{X}$ та Хс-ЛПНЩ у групі гіпертиреозу може свідчити про дис- 
функції на рівні тиреоїдних рецепторів, які посилюються за додаткового емоційного стресу.

Нетипова відповідь на стрес імовірна за певних генетичних особливостей індивідів чи за впливу окремих факторів середовища. За тривалої чи кількаразової (із постійним нарощуванням інтенсивності стресора) стресової дії можливий розвиток метаболічних дисфункцій (Mathe, 2000).

Виявлені нами в мешканців радіаційно забруднених територій особливості ліпідного профілю справді мали типові ознаки метаболічного синдрому, описані в науковій літературі: дисліпідемія, що характеризується підвищенням рівня тригліцеридів і Хс-ЛПНЩ, зниженим рівнем Хс-ЛПВЩ. Ці аномалії вважають тісно пов'язаними 3 підвищеним окисним стресом i ендотеліальними дисфункціями (Barter et al., 2007; Prasad et al., 2012; Kaur, 2014). Ступінь прояву дисліпідемії та ії зв’зку з тиреоїдними дисфункціями ще не дозволяє говорити про наявність в обстежених вираженої патології, проте може свідчити про вичерпування адаптаційних ресурсів систем підтримання гомеостазу та формування потенційних груп ризику. Слід враховувати, що порушення функції щитоподібної залози пов'язані з порушеннями ліпідного обміну патогенетично, оскільки відігріють ключову роль у ліпідному та ліпопротеїновому метаболізмі (Mustafina, 2010).

\section{Висновки}

В осіб, які тривалий час проживали на територіях, забруднених радіонуклідами внаслідок аварії на ЧАЕС, спостерігаються проатерогенні зміни, залежні від тиреоїдного статусу, що можуть стати передумовами розвитку метаболічного синдрому. Ризик виникнення дисліпідемій зростає в умовах додаткового психоемоційного навантаження, коли нівелюється регуляторний ефект гормонів щитоподібної залози. Хронічний вплив малих доз іонізуючого випромінювання зумовлює ризик порушення адаптаційних можливостей тиреоїдного статусу, що, у свою чергу, відображається на стані ліпідного обміну.

\section{References}

Abou-El-Ardat, K., Monsieurs, P., Anastasov, N., Atkinson, M., Derradji, H., De Meyer, T., Bekaert, S., Van Criekinge, W., \& Baatout, S. (2012). Low dose irradiation of thyroid cells reveals a unique transcriptomic and epigenetic signature in RET/PTC-positive cells. Mutation Research/Fundamental and Molecular Mechanisms of Mutagenesis, 731(1), 27-40.

Abrams, J. J., \& Grundy, S. M. (1981). Cholesterol metabolism in hypothyroidism and hyperthyroidism in man. Journal of Lipid Research, 22(2), 323-338.

Agbaht, K., Mercan, Y., Kutlu, S., Alpdemir, M. F., \& Sezgin, T. (2014). Obesity with and without metabolic syndrome: Do vitamin D and thyroid autoimmunity have a role? Diabetes Research and Clinical Practice, 106(1), 27-34.

Badawy, E. S., \& Ghonium, S. M. (2013). Thyroid stimulating hormone as risk factor for coronary heart disease. Science Journal of Medicine and Clinical Trial, 2013, 1-4

Baker, J. E., Moulder, J. E., \& Hopewell, J. W. (2011). Radiation as a risk factor for cardiovascular disease. Antioxidants and Redox Signaling, 15(7), 1945-1956

Balaeva-Tikhomirova, O. M. (2014). Otdalennye posledstvija stress-reakcii na dlitel'noe vozdejstvie hronicheskogo nervno-psihicheskogo naprjazhenija [Long-term effects of stress reaction on long-term exposure of chronic neuropsychological tension]. In: Specificheskie i nespecificheskie mehanizmy adaptacii vo vremja stressa i fizicheskoj nagruzki [Specific and non-specific mechanisms of adaptation during stress and physical load]. GomGMU, Gomel'. Pp. 3-5 (in Russian).

Barter, P., Gotto, A. M., LaRosa, J. C., Maroni, J., Szarek, M., Grundy, S. M., Kastelein, J. J., Bittner, V. \& Fruchart, J. C. (2007). HDL cholesterol, very low levels of LDL cholesterol, and cardiovascular events. New England Journal of Medicine, 357(13), 1301-1310.

Beckham, J. C., Taft, C. T., Vrana, S. R., Feldman, M. E., Barefoot, J. C., Moore, S. D., Mozley, S. L., Butterfield, M. I., \& Calhoun, P. S. (2003). Ambulatory monitoring and physical health report in Vietnam veterans with and without chronic posttraumatic stress disorder. Journal of Traumatic Stress, 16(4), 329-335.
Benetti-Pinto, C. L., Piccolo, V. R. S. B., Garmes, H. M., \& Juliato, C. R. T. (2013). Subclinical hypothyroidism in young women with polycystic ovary syndrome: An analysis of clinical, hormonal, and metabolic parameters. Fertility and Sterility, 99(2), 588-592.

Beyhan, Z., Ertürk, K., Üçkaya, G., Bolu, E., Yaman, H., \& Kutlu, M. (2006). Restoration of euthyroidism does not improve cardiovascular risk factors in patients with subclinical hypothyroidism in the short term. Journal of Endocrinological Investigation, 29(6), 505-510.

Brotman, D. J., Golden, S. H., \& Wittstein, I. S. (2007). The cardiovascular toll of stress. The Lancet, 370(9592), 1089-1100.

Bruno, R. M., Sicari, R., Corciu, A. I., Bianchini, E., Faita, F., Di Stefano, R., Antonelli, A., Ghiadoni, L. \& Picano, E. (2013). Non-cancer atherosclerotic effects associated with environmental and therapeutic radiation doses: The Chernobyl thyroid cancer children study. International Journal of Cardiology, 168(4), 4255-4257.

Bul'ba, Y., Barylyak, L. G., Huchko, B. Y. (2006). Vzayemozv'yazky mizh parametramy lipidnoho ta endokrynnoho statusiv u zhinok $\mathrm{z}$ hiperplaziyeyu shchytovydnoyi zalozy, kotri prybuvayut' na kurort Truskavets'. Povidomlennya 2: Dyskryminantnyy ta korelyatsiyno-rehresyvnyy analiz [The relationships between parameters of lipid and enocrine status in women with hyperplasia of thyroid glands. communication 2: The dyscriminant and correlative-regressive analyses]. Medychna Hidrolohiya ta Reabilitatsiya, 4(3), 45-64 (in Ukrainian).

Cardis, E., \& Hatch, M. (2011). The Chernobyl accident - an epidemiological perspective. Clinical Oncology, 23(4), 251-260.

Chang, I. Y., Ohn, T., Ko, G. S., Yoon, Y., Kim, J. W., \& Yoon, S. P. (2012). Immunolocalization of steroidogenic acute regulatory protein-related lipid transfer (START) domain-containing proteins in the developing cerebellum of normal and hypothyroid rats. Journal of chemical neuroanatomy, 43(1), 28-33.

Contis, G., \& Foley Jr, T. P. (2015). Depression, suicide ideation, and thyroid tumors among Ukrainian adolescents exposed as children to Chernobyl radiation. Journal of clinical medicine research, 7(5), 332-338.

Davis, S. R., Shah, S. M., McKenzie, D. P., Kulkarni, J., Davison, S. L., \& Bell, R. J. (2008). Dehydroepiandrosterone sulfate levels are associated with more favorable cognitive function in women. The Journal of Clinical Endocrinology and Metabolism, 93(3), 801-808.

Dedecjus, M., Masson, D., Gautier, T., De Barros, J. P. P., Gambert, P., Lewinski, A., Adamczewski, Z., Moulin, P., \& Lagrost, L. (2003). Low cholesteryl ester transfer protein (CETP) concentration but normal CETP activity in serum from patients with short-term hypothyroidism Lack of relationship to lipoprotein abnormalities. Clinical Endocrinology, 58(5), 581-588.

Duntas, L. H. (2003). Lipoprotein (a) and apolipoprotein (a) isoform size in thyroid disease: The quest for the golden fleece. Thyroid, 13, 345-346.

Duntas, L. H., \& Brenta, G. (2012). The effect of thyroid disorders on lipid levels and metabolism. Medical Clinics of North America, 96(2), 269-281.

Engelking, L. R. (2010). Textbook of veterinary physiological chemistry. Academic Press.

Ezzaher, A., Mouhamed, D. H., Mechri, A., Neffati, F., Douki, W., Gaha, L., \& Najjar, M. F. (2011). Thyroid function and lipid profile in bipolar I patients. Asian Journal of Psychiatry, 4(2), 139-143.

Fushiki, S. (2013). Radiation hazards in children-lessons from Chernobyl, Three Mile Island and Fukushima. Brain and Development, 35(3), 220-227.

Garasto, S., Montesanto, A., Corsonello, A., Lattanzio, F., Fusco, S., Passarino, G., Prestipino Giarritta, V. \& Corica, F. (2017). Thyroid hormones in extreme longevity. Mechanisms of Ageing and Development.

Iqbal, A., Jorde, R., \& Figenschau, Y. (2006). Serum lipid levels in relation to serum thyroid-stimulating hormone and the effect of thyroxine treatment on serum lipid levels in subjects with subclinical hypothyroidism: The Tromsø Study. Journal of Internal Medicine, 260(1), 53-61.

Janssen, I., Katzmarzyk, P. T., Srinivasan, S. R., Chen, W., Malina, R. M., Bouchard, C., \& Berenson, G. S. (2005). Combined influence of body mass index and waist circumference on coronary artery disease risk factors among children and adolescents. Pediatrics, 115(6), 1623-1630.

John, D., Boice Jr. (2017). Chapter 3 - From Chernobyl to Fukushima and Beyond - A focus on thyroid cancer. Thyroid cancer and nuclear accidents. Long-term aftereffects of Chernobyl and Fukushima, 21-32.

Kannisto, K., Rehnmark, S., Slätis, K., Webb, P., Larsson, L., Gafvels, M., Eggertsen, G., \& Parini, P. (2014). The thyroid receptor $\beta$ modulator GC-1 reduces atherosclerosis in ApoE deficient mice. Atherosclerosis, 237(2), 544-554.

Kaur, J. (2014). A comprehensive review on metabolic syndrome. Cardiology research and practice, 2014, 943162.

Klein, J. R., \& Wang, H. C. (2004). Characterization of a novel set of resident intrathyroidal bone marrow-derived hematopoietic cells: potential for immune-endocrine interactions in thyroid homeostasis. Journal of experimental biology, 207(1), 55-65.

Korenev, M. M., Plekhova, O. I., Kalmykova, N. V., Kashina, V. L., \& Borisko, G. O. (2009). Osoblyvosti lipidnoho spektru krovi u nashchadkiv likvidatoriv avariyi na ChAES [Some features of blood 
lipid spectrum in descendants of the liquidators Chernobyl disaster]. Sovremennaja Pediatrija, 25, 56-58 (in Ukrainian).

Kushnarova, N. M., Korpachev, V. V., Korpacheva-Zinych, A. V., Hurina N. M., \& Prybyla, A. V. (2016). Vidnoshennya kortyzol/DHEA ta pokaznyky lipidnoho profilyu syrovatky krovi khvorykh na tsukrovyy diabet 2 typu $\mathrm{z}$ riznym indeksom vistseral'noho ozhyrinnya [The correlation of cortisol/DHEA and parameters of lipid profile of blood serum of patients with diabetes II type, with a different index of visceral obesity]. ScienceRise Medical Science, 1(3), 19-25 (in Ukrainian).

Laclaustra, M., Hurtado-Roca, Y., Sendin, M., Leon, M., Ledesma, M., Andres, E., Fernandez-Ortiz, A., Guallar, E., Ordovas, J. M. \& Casasnovas, J. A. (2015). Lower-normal TSH is associated with better metabolic risk factors: A cross-sectional study on Spanish men. Nutrition, Metabolism and Cardiovascular Diseases, 25(12), 1095-1103.

Lindemann, J. A. L., Angajala, A., Engler, D. A., Webb, P., \& Ayers, S. D. (2014). Thyroid hormone induction of human cholesterol 7 alphahydroxylase (Cyp7a1) in vitro. Molecular and Cellular Endocrinology, 388(1), 32-40.

Machado, T. D., Salum, G. A., Bosa, V. L., Goldani, M. Z., Meaney, M. J., Agranonik, M., Manfro, G. G., \& Silveira, P. P. (2015). Early life trauma is associated with decreased peripheral levels of thyroid-hormone $T_{3}$ in adolescents. International Journal of Developmental Neuroscience, 47, 304-308.

Marwaha, R. K., Tandon, N., Garg, M. K., Kanwar, R., Sastry, A., Narang, A., Arora, S., \& Bhadra, K. (2011). Dyslipidemia in subclinical hypothyroidism in an Indian population. Clinical Biochemistry, 44(14), 1214-1217.

Mathe, G. (2000). The need of a physiologic and pathophysiologic defi nition of stress. Biomedicine and Pharmacotherapy, 54, 119-121.

Michel, R., Daraoui, A., Gorny, M., Jakob, D., Sachse, R., Romantschuk, L. D., Alfimov, V., \& Synal, H. A. (2015). Retrospective dosimetry of Iodine-131 exposures using Iodine-129 and Caesium-137 inventories in soils - A critical evaluation of the consequences of the Chernobyl accident in parts of Northern Ukraine. Journal of Environmental Radioactivity, 150, 20-35.

Moncayo, R., \& Moncayo, H. (2017). Applying a systems approach to thyroid physiology: Looking at the whole with a mitochondrial perspective instead of judging single TSH values or why we should know more about mitochondria to understand metabolism. BBA Clinical, 7, 127-140.

Mustafina, S. V., Rimar, O. D., Simonova, G. I., Ragino, Y. I., Kuznetsov, S. S., Scherbakova, L. V., \& Malyutina, S. K. (2010). Funkcional'noe sostojanie shhitovidnoj zhelezy i lipidnyj profil' krovi [Functional state of thyroid gland and lipid blood profile]. Ateroskleroz, 6(2), 15-19 (in Russian).

Nikolaev, N. A., Kolbina, M. V., Livzan, N. A., Dolgikh, V. T., Sudakova, A. N. (2012). Tireoidnyj profil' u bol'nyh IBS i gipertonicheskoj bolezn'ju pri narushenijah ritma serdca [Thyroid profile in patients with CHD (coronal heart disease) and hypertension along with heart rhythm abnormalities] Mezhdunarodnyj Zhurnal Jeksperimental'nogo Obrazovanija, 12, 108-109 (in Russian).

O’Connor, D. B., Hendrickx, H., Dadd, T., Elliman, T. D., Willis, T. A., Talbot, D., Mayes, A. E., Thethi, K., Powell, J., \& Dye, L. (2009). Cortisol awakening rise in middle-aged women in relation to psychological stress. Psychoneuroendocrinology, 34(10), 1486-1494.

Peng, R., \& Li, Y. (2017). Low serum thyroid-stimulating hormone levels are associated with lipid profile in depressive patients with long symptom duration. Journal of Affective Disorders, 217, 99-104.

Pirich, C., Müllner, M., \& Sinzinger, H. (2000). Prevalence and relevance of thyroid dysfunction in 1922 cholesterol screening participants. Journal of Clinical Epidemiology, 53(6), 623-629.

Popovych, I. L., Fliunt, I. S., Alieksieiev, O. I., Baryliak, L. H., \& Bilas, V. R. (2003). Sanogenetychni zasady reabilitacii' na kurorti Truskavec' urologichnyh hvoryh chornobyl's'kogo kontyngentu [Sanogenetic principles of rehabilitation of urological patients of Chornobyl contingent at Truskavets resort]. Komp'juterpres, Kyiv (in Ukrainian).

Prasad, H., Ryan, D. A., Celzo, M. F., \& Stapleton, D. (2012). Metabolic syndrome: Definition and therapeutic implications. Postgraduate Medicine, 124(1), 21-30.

Racine, R., Grandcolas, L., Grison, S., Gourmelon, P., Gueguen, Y., Veyssiere, G., \& Souidi, M. (2009). Molecular modifications of cholesterol metabolism in the liver and the brain after chronic contamination with cesium 137. Food and Chemical Toxicology, 47(7), 1642-1647.

Radišauskas, R., Kuzmickienė, I., Milinavičiene, E., \& Everatt, R. (2016). Hypertension, serum lipids and cancer risk: A review of epidemiological evidence. Medicina, 52(2), 89-98.
Rahu, K., Hakulinen, T., Smailyte, G., Stengrevics, A., Auvinen, A., Inskip, P. D., Boice, J. D. Jr. \& Rahu, M. (2013). Site-specific cancer risk in the Baltic cohort of Chernobyl cleanup workers, 1986-2007. European Journal of Cancer, 49(13), 2926-2933.

Rhee, S. J., Kim, E. Y., Kim, S. H., Lee, H. J., Kim, B., Ha, K., Yoon, D. H., \& Ahn, Y. M. (2014). Subjective depressive symptoms and metabolic syndrome among the general population. Progress in NeuroPsychopharmacology and Biological Psychiatry, 54, 223-230.

Rumiantsev, P. O., Saenko, V. A., \& Dedov, I. I. (2017). Chapter $10-$ Influence of radiation exposure and ultrasound screening on the clinical behavior of papillary thyroid carcinoma in young patients. Thyroid cancer and nuclear accidents. Long-term aftereffects of Chernobyl and Fukushima, 97-107.

Sharma, P., Levesque, T., Boilard, E., \& Park, E. A. (2014). Thyroid hormone status regulates the expression of secretory phospholipases. Biochemical and Biophysical Research Communications, 444(1), 56-62.

Shavdatuashvili, T. (2005). Lipoprotein profile and endothelial function in patients with subclinical and overt hypothyroidism. Georgian Medical News, 129, 57-60.

Shoji, T., Emoto, M., Nishizawa, Y., \& Inaba, M. (2015). Endocrine and metabolic changes affecting cardiovascular disease in dialysis patients. Journal of Renal Nutrition, 25(2), 223-225.

Sinha, R. A., Singh, B. K., \& Yen, P. M. (2014). Thyroid hormone regulation of hepatic lipid and carbohydrate metabolism. Trends in Endocrinology and Metabolism, 25(10), 538-545.

Sokolenko, V. L. (2016). Pokaznyky kholesterynu ta imunnoyi systemy u osib z oznakamy veheto-sudynnoyi dystoniyi, shcho prozhyvaly na terytoriyakh, zabrudnenykh radionuklidamy [Cholesterol rate and immune system indices in people with symptoms of vegetative-vascular dystonia, who lived in the territories contaminated with radionuclides]. Svit Medytsyny ta Biolohiyi, 2, 86-90 (in Ukrainian).

Takamura, N., Orita, M., Saenko, V., Yamashita, S., Nagataki, S., \& Demidchik, Y. (2016). Radiation and risk of thyroid cancer: Fukushima and Chernobyl. The Lancet Diabetes and Endocrinology, 4(8), 647.

Takeuchi, H. (2015). Serum levels of free $T_{3}$ are associated with ApoA1 and ApoA2, whereas free $T_{4}$ levels are associated with ApoB and LDLcholesterol in euthyroid cardiovascular patients. IJC Metabolic and Endocrine, 8, 1-6.

Taub, R., Chiang, E., Chabot-Blanchet, M., Kelly, M. J., Reeves, R. A Guertin, M. C., \& Tardif, J. C. (2013). Lipid lowering in healthy volunteers treated with multiple doses of MGL-3196, a liver-targeted thyroid hormone receptor- $\beta$ agonist. Atherosclerosis, 230(2), 373-380.

Terán, V. S., \& Calle, M. A. A. (2012). Relationship of thyroid-stimulating hormone levels to development of dyslipidemia and determination of an ideal cut-off point for start replacement therapy. Endocrinología y Nutrición (English Edition), 59(10), 575-582.

Toth, P. P., Grabner, M., Punekar, R. S., Quimbo, R. A., Cziraky, M. J., \& Jacobson, T. A. (2014). Cardiovascular risk in patients achieving low-density lipoprotein cholesterol and particle targets. Atherosclerosis, 235(2), 585-591.

Tronko, N. D., Cheban, A. K., Oliinyk, V. A., \& Epshtein, Y. V. (1996). Klinichni aspekty Chornobyl's'koyi katastrofy. Endokrynna systema [Clinical aspects of the Chornobyl disaster. The endocrine system]. In: Chornobyl's'ka katastrofa. Ed. V. H. Bariakhtar. Scientific View, Kyiv (in Ukrainian).

van den Berg, E. H., van Tienhoven-Wind, L. J., Amini, M., Schreuder, T. C., Faber, K. N., Blokzijl, H., \& Dullaart, R. P. (2017). Higher free triiodothyronine is associated with non-alcoholic fatty liver disease in euthyroid subjects: The lifelines cohort study. Metabolism, 67, 62-71.

van Tienhoven-Wind, L., \& Dullaart, R. P. (2015). Low normal thyroid function as a determinant of increased large very low density lipoprotein particles. Clinical Biochemistry, 48(7), 489-494.

Vermes, I., \& Beishuizen, A. (2007). The neuroendocrinology and immunology of critical illness. Neuroimmune Biology, 7, 291-317.

Zak, B. (1980). Cholesterol methodology for human studies. Lipids, 15(9), 698-704.

Zhang, T., Zhou, L., cong Li, C., Shi, H., \& Zhou, X. (2016). TSH increases synthesis of hepatic ATP-binding cassette subfamily A member 1 in hypercholesterolemia. Biochemical and Biophysical Research Communications, 476(2), 75-81.

Zhigulina, V. V. (2015). Biohimicheskij otvet na stress (obzor literatury) [Biochemical response to stress (overview)]. Tverskoj Medicinskij Zhurnal, 1, 91-100 (in Russian). 